Weathering the storm: Ownership structure and performance of microfinance institutions in the wake of the global financial crisis

Mahinda Wijesiri

Indira Gandhi Institute of Development Research, Mumbai January 2016 http://www.igidr.ac.in/pdf/publication/WP-2016-002.pdf 


\title{
Weathering the storm: Ownership structure and performance of microfinance institutions in the wake of the global financial crisis
}

\author{
Mahinda Wijesiri \\ Indira Gandhi Institute of Development Research (IGIDR) \\ General Arun Kumar Vaidya Marg \\ Goregaon (E), Mumbai- 400065, INDIA \\ Email(corresponding author): mahindaw@igidr.ac.in
}

\begin{abstract}
This study investigates the effects of the 2008 global financial crisis on the performance of different microfinance ownership types. The analysis in this study relies on a novel methodological framework that provides consistent productivity measures in the presence of undesirable outputs, while taking into account the technological heterogeneity among different ownership types. The results show that banks and non-bank financial institutions (NBFIs) that performed better immediately before the crisis, suffered more during the crisis and early post-crisis periods. Cooperatives and non-governmental organizations (NGOs), on the other hand, were less affected by the crisis. Moreover, results indicate that the pattern of productivity growth of all ownership forms three years after the eruption of the crisis was remarkably similar to their productivity growth pattern in the very early phase of the pre-crisis period.
\end{abstract}

Keywords: Microfinance; Ownership; Metafrontier; Malmquist-Luenberger; Productivity change; Global Financial Crisis

JEL Code: C61; D24; G01; G21 
Weathering the storm: Ownership structure and performance of microfinance institutions in the wake of the global financial crisis

\author{
Mahinda Wijesiri \\ IGIDR-IDRC Postdoctoral Fellowship Program \\ Indira Gandhi Institute of Development Research (IGIDR) \\ General Arun Kumar Vaidya Marg \\ Goregaon (E), Mumbai- 400065, India \\ mahindaw@igidr.ac.in
}

\begin{abstract}
This study investigates the effects of the 2008 global financial crisis on the performance of different microfinance ownership types. The analysis in this study relies on a novel methodological framework that provides consistent productivity measures in the presence of undesirable outputs, while taking into account the technological heterogeneity among different ownership types. The results show that banks and non-bank financial institutions (NBFIs) that performed better immediately before the crisis, suffered more during the crisis and early postcrisis periods. Cooperatives and non-governmental organizations (NGOs), on the other hand, were less affected by the crisis. Moreover, results indicate that the pattern of productivity growth of all ownership forms three years after the eruption of the crisis was remarkably similar to their productivity growth pattern in the very early phase of the pre-crisis period.
\end{abstract}

Keywords: Microfinance; Ownership; Metafrontier; Malmquist-Luenberger; Productivity change; Global Financial Crisis

JEL classification: C61; D24; G01; G21 


\section{Introduction}

Recent decades have seen a massive expansion in the microfinance industry (Kevane \& Wydick, 2001; Louis et al. 2013), generating entrepreneurial opportunities for the marginalized and vulnerable groups who are often excluded from the traditional financial system. The Microcredit Summit Campaign Report 2015 (www.microcreditsummit.org) reveals that at the end of 2013, microfinance institutions (MFIs) served approximately 211 million clients, more than half of whom were among the poorest when they applied for their first loan. The above report further indicates that the total number of the poorest clients with outstanding loans declined for the third consecutive year, from 116 million in 2012 to 114 million in 2013, a reduction that clearly reflects the efforts of MFIs to promote financial inclusion in developing countries. While a healthy microfinance system is huge source of benefit for the less well-off in emerging markets (Armendáriz \& Morduch, 2005), any failure of the industry can have devastating consequences for the entire economy. This was witnessed the 2008 global financial crisis, which led not only to the collapse of large formal financial institutions (Schubert, 2011; Beltratti \& Stulz, 2012; Kollmann, 2013) but also to considerable downturns in the microfinance industry (Wagner, 2012; Wagner \& Winkler, 2013) comprising a substantial proportion of the financial market in developing economies. In this context, Wagner (2012) comments that '..., by becoming part of the global financial system, microfinance has lost one of the characteristics distinguishing it from traditional banking, namely, its greater resilience to crises in domestic and global financial markets'. However, that the question arises whether all MFIs have been affected by the crisis equally. Because different microfinance ownership types use different technologies, and consequently have different efficiency levels (Servin et al., 2012), it may be more logical to argue that the effects of the crisis on MFI performance may differ from one ownership form to another. In fact microfinance ownerships simply have too many variables: different regulatory and supervisory mechanisms, different agency problems, different governance models as well as different levels of risk preferences (Tchakoute-Tchuigoua, 2010; Servin et al., 2012). For instance, banks and non-bank financial institutions (NBFIs) are shareholder institutions and put more weight on financial returns. Cooperatives and non-governmental organizations (NGOs), on the other hand, are non-regulated and more socially-oriented. Unlike non-regulated ownership types, banks and NBFIs are regulated and hence have more opportunities to offer a wider range of products and services (Tchakoute-Tchuigoua, 2010). Yet systemic risk of shareholder 
institutions is higher compared to that of cooperatives and NGOs (Bella, 2011). Given these differences in microfinance ownership structure, the effects of the crisis on MFI performance can be more drastic for some ownership types and less drastic for others. For example, the crisis may have had a severe impact on NGOs that have transformed into other shareholding entities, i.e. NBFIs. To accomplish their financial objectives, as they transformed, and with many of them relying on their funding relationships with local and foreign capital markets, such transformed institutions would suffer severe losses and even go bankrupt if the capital market fails. Another example is state-owned development banks. They are more likely to have experienced a substantial adverse effect at the time of economic uncertainty due to political interventions. Strategic decisions of some state-owned microfinance banks are often biased by political motivations (e.g., subsidized lending to supporters to secure their political survival). Such interventions, particularly in a turbulent environment, place the top management in a difficult situation that can eventually lead these institutions being in distress.

In this context, an analysis of the efficiency and productivity dynamics of different microfinance ownership types, particularly in the midst of a financial turmoil, is likely to be important for policy evaluation. Since the performance of a financial institution in past crises not only provides a measure of its exposure to systemic risk but also predicts its performance in another crisis (Fahlenbrach et al., 2012), realizing which ownerships fail and which weather the storm without disruption helps policymakers and regulators to design risk-focused monetary policies. Such information is also useful for donors, investors and incumbent MFIs or, perhaps more importantly, NGOs thinking of transforming in to for-profit ownership types to develop more innovative operating programs. So far, however, there has been little discussion about the performance of MFIs under the effect of financial crisis.

It is against this backdrop, that I investigate the effects of the global financial crisis on productivity dynamics of different microfinance ownership types. My study is based on a crosscountry analysis of a sample of 298 MFIs, for which I have consistent data on the relevant variables for the period 2005-2011. I split the entire time period into three sub-periods and then explored the productivity levels of different microfinance ownership types before (2005-2007), during (2007-2008) and after the global financial crisis (2008-2011). Using pre- and post- crisis 
periods as benchmarks, I explored which ownership types were more robust to the crisis and which were more affected by the crisis.

The present study is related to two broad strands of research. The first category evaluates the link between microfinance ownership types and performance (e.g., Mersland \& Strøm, 2008; Mersland \& Strøm, 2009; Servin et al., 2012). The second group discusses microfinance performance in the wake of the financial crisis (e.g., Patten \& Johnston, 2001; Constantinou \& Astha, 2011; Bella, 2011; Wagner, 2012; Wagner \& Winkler, 2013). In this study, I combine these two research strands by empirically investigating the impact of the crisis on the performance of MFIs with different ownership status.

The present study updates the literature of MFI efficiency and productivity dynamics. Updating those empirical studies is vital given the rapid financial reforms that have occurred in the financial market, particularly in response to the implications drawn from the recent financial turmoil. This study is distinct from the existing microfinance literature of MFI efficiency and productivity in several aspects. First, much of the earlier empirical studies so far are about one country (e.g., Nghiem et al., 2006; Piot-Lepetit \& Nzongang, 2014; Wijesiri et al., 2015) or take a regional perspective (e.g., Gutiérrez-Nieto et al., 2007; Paxton, 2007; Servin et al., 2012). Moreover, all of these studies except, for that of Wijesiri \& Meoli (2015), are based on crosssectional data that restricts the use of panel data econometric methods. However, no empirical study for the period 2005-2012 is known to the author, and thus no evidence exists of the impacts of the global financial crisis on MFI performance. In the present study, I examine MFIs from a large number of countries. The use of time-series data in this research is also advantageous. Second, none of the earlier studies, to my knowledge, accounts for undesirable outputs in measuring MFI efficiency, i.e. non-performing loans (NPLs). Given the collateral-free lending method adopted by many MFIs, loan portfolios are more likely to be volatile and weak, especially in an event of financial distress. Thus, it is important to consider the effect of the growing volume of NPLs in the production process for meaningful comparison. For example, Mester (1996) emphasizes the importance of taking into account the quality and risk of loans when analyzing bank efficiency, because banks that produce risky loans could be labeled as efficient and more productive when compared to more responsible banks with low NPLs. In order to escape from inaccurate benchmarking, I, therefore, introduce undesirable output NPLs 
that are a byproduct of the production process into my models. Third, from a methodological perspective, the novelty of the current paper lies in the use of a Malmquist Luenberger Productivity Index (MLPI) combined with a metafrontier concept. I do not use the conventional Malmquist Productivity Index (MPI) in this research, since this method, albeit widely used, does not credit reduction of undesirable outputs. Instead, it expands both desirable and undesirable outputs at the same rate. To the contrary, the MLPI developed by Chung et al. (1997) gives credit firms for proportionate increases in desirable outputs and proportionate decreases in undesirable outputs. This index allows the derivation of consistent productivity measures in the presence of undesirable outputs, but does not take into account the technological heterogeneity among different microfinance ownership types. One way to solve this problem is the metafrontier concept proposed by O'Donnell et al. (2008) in the non-parametric data envelopment analysis (DEA) framework. This approach provides a homogeneous boundary for MFIs operating under different production technologies. In this study, I combine the metafrontier concept and Malmquist Luenberger Productivity indices and estimate the comparable productivity measures for the MFIs with different ownership status. Finally, I decompose the MLPI into two components, namely, changes in efficiency and technology, to determine the sources of productivity changes over time. As such, I am better able to isolate the impact of the financial crisis on the productivity of MFIs with different ownership structures.

The reminder of the paper unfolds as follows. Section 2 presents the methodology. Section 3 describes the data and variables used. Results are presented in section 4 and section 5 concludes.

\section{Methodology}

In this section, I briefly describe the methodological approaches followed in my analysis. First, I present the underlying assumptions and then describe the directional distance functions on which the MLPI is based. Next, I illustrate the formulation of MLPI and its decompositions. Finally, I discuss the combination of both the metafrontier concept and MLPI to construct the groupfrontiers and metafrontier.

\subsection{The fundamental assumptions}


I assume that there are $\mathrm{j}(1, \ldots, \mathrm{J})$ decision making units (DMUs) using $\mathrm{N}$ inputs $\left(x \in R_{+}^{N}\right)$ to produce $\mathrm{M}$ desirable outputs $\left(y \in R_{+}^{M}\right)$ and $\mathrm{L}$ undesirable outputs $\left(b \in R_{+}^{L}\right)$. The set of production possibilities for each DMU is defined as:

$$
P(x)=\{(y, b): x \text { can produce }(y, b)\}, x \in R_{+}^{N}
$$

Referring to Färe et al. (2007), following three axioms are used to specify the production possibility set with undesirable outputs.

$$
\begin{aligned}
& \text { if }(y, b) \in P(x) \text { and } b=0 \text { then } y=0 \\
& (y, b) \in P(x) \text { and } y^{\prime} \leq y \text { imply } y^{\prime} \in P(x) \\
& (y, b) \in P(x) \text { and } 0 \leq \emptyset \leq 1 \text { imply }(\varnothing y, \emptyset b) \in P(x)
\end{aligned}
$$

The first axiom shown in Eq. (2a) indicates that the good and bad outputs are "null-joint": that is, no good outputs can be produced unless some of the bad outputs are also produced. The axiom in Eq. (2b) designates that good outputs are freely disposable. This involves assuming that good outputs may be reduced without the reduction of the bad outputs. The third axiom in Eq. (3b) means that good and bad outputs are jointly weakly disposable. That is, any reduction in bad outputs is costly.

\subsection{Directional distance function}

Conventional MPI defined by Färe et al, (1994) is based on the Shephard's output distance functions (Shephard, 1970). Thus, it credits only for increases in desirable outputs. Use of conventional MPI to measure the productivity in the presence of undesirable outputs, therefore, leads to yield biased estimates. Chung et al. (1997) address this issue by proposing the MLPI. This method is based on the directional distance functions that allow expanding the desirable outputs while simultaneously contracting the undesirable outputs. Thus, it quantifies the negative effects of NPLs on MFI performance.

Following Chung et al. (1997), the directional output distance function in the base period $t$ is defined as follow:

$$
\overrightarrow{D_{t}}\left(x_{t}, y_{t}, b_{t}, g_{y t}, g_{b t}\right)=\sup \left\{\beta_{t}:\left(x_{t}, y_{t}+\beta_{t} g_{y t}, b_{t}+\beta_{t} g_{b t}\right) \in P_{t}\left(x_{t}\right)\right\}
$$

Where $g=\left(g_{y}, g_{b}\right)$ is the directional vector in which outputs are scaled (i.e., desirable outputs are increased and undesirable outputs are decreased); $\beta$ is the directional output distance function, and it increases the desirable outputs (y) while simultaneously reducing the undesirable outputs (b) along the direction vector $(\mathrm{g})$. 


\subsection{Malmquist Luenberger Productivity Index and its decompositions}

Following Chung et al. (1997), output-oriented MLPI between time period $t$ and $(t+1)$ is defined as a geometric mean of the Malmquist Lunenberger Productivity indices,

$M L P I_{t, t+1}=\left\{\frac{1 /\left[1+\vec{D}_{t}\left(x_{t+1}, y_{t+1}, b_{t+1} ; g_{y t+1}, g_{b t+1}\right)\right]}{1 /\left[1+\vec{D}_{t}\left(x_{t}, y_{t}, b_{t} ; g_{y t}, g_{b t}\right)\right]} X \frac{1 /\left[1+\vec{D}_{t+1}\left(x_{t+1}, y_{t+1}, b_{t+1} ; g_{y t+1}, g_{b t+1}\right)\right]}{1 /\left[1+\vec{D}_{t+1}\left(x_{t}, y_{t}, b_{t} ; g_{y t}, g_{b t}\right)\right]}\right\}^{1 / 2}$

MLPI can be further decomposed into efficiency change (EC) and technical change (TC) as follows:

$$
\begin{aligned}
& M L P I_{t, t+1}= \\
& \underbrace{\frac{1+\vec{D}_{t}\left(x_{t}, y_{t}, b_{t} ; g_{y t}, g_{b t}\right)}{1+\vec{D}_{t+1}\left(x_{t+1}, y_{t+1}, b_{t+1} ; g_{y t+1}, g_{b t+1}\right)}}_{\text {Efficiency Change }} \times \underbrace{\left[\frac{1+\vec{D}_{t+1}\left(x_{t}, y_{t}, b_{t} ; g_{y t}, g_{b t}\right)}{1+\vec{D}_{t}\left(x_{t}, y_{t}, b_{t} ; g_{y t}, g_{b t}\right)} X \frac{1+\vec{D}_{t+1}\left(x_{t+1}, y_{t+1}, b_{t+1} ; g_{y t+1}, g_{b t+1}\right)}{1+\vec{D}_{t}\left(x_{t+1}, y_{t+1}, b_{t+1} ; g_{y t+1}, g_{b t+1}\right)}\right]^{1 / 2}}_{\text {Technical Change }}
\end{aligned}
$$

Eq. (5) can be defined as a simplified expression as follows:

$$
M L P I_{t, t+1}=E C_{t, t+1} \times T C_{t, t+1}
$$

EC ('catching up') indicates the convergence towards or divergence from the best practice on part of remaining DMUs whereas TC ('innovation') reflects improvement or deterioration in the performance of best-practice DMUs (Casu et al., 2004). As in the case of conventional MPI, for MLPI and its components, a values greater than unity indicates a progress whereas a values less than unity implies a regression. A value equals to unity implies no change in the performance measures being referred to.

\subsection{Metafrontier approach}

While productivity measures obtained using MLPI developed by Chung et al. (1997) are comparable for DMUs operating under same technologies (e.g., MFIs belonging to same ownership structure), this is not the case among DMUs that operate under different production technologies. Since MLPI does not take into account the heterogeneity among different DMUs, I turn to a modified version of this index which is referred to as metafrontier Malmquist Luenberger Productivity Index (MMLPI). To do so, I combine MLPI with the concept of 
metafrontier production function. The new index provides an unbiased productivity comparison for DMUs operating under different production technologies.

In the present study, I follow O'Donnell et al. (2008), and define MLPI with respect to the group frontier and with respect to the metafrontier. Assuming that Eq. (1) to (4) are group based measures, I define MLPI in Eq. (4) as the group Malmquist Luenberger Productivity Index (GMLPI).

GMLPI for a DMU belonging to the $a^{\text {th }}$ group is thus;

$G M L P I_{t, t+1}=\frac{1+\overrightarrow{D_{t}^{a}}\left(x_{t}^{a}, y_{t}^{a}, b_{t}^{a} ; g_{y t}^{a}, g_{b t}^{a}\right)}{1+\overline{D_{t+1}^{a}}\left(x_{t+1}^{a}, y_{t+1}^{a}, b_{t+1}^{a} ; g_{y t+1}^{a}, g_{b t+1}^{a}\right)} \times\left[\frac{1+\overrightarrow{D_{t+1}^{a}}\left(x_{t}^{a}, y_{t}^{a}, b_{t}^{a} ; g_{y t}^{a}, g_{b t}^{a}\right)}{1+\overline{D_{t}^{a}}\left(x_{t}^{a}, y_{t}^{a}, b_{t}^{a} ; g_{y t}^{a}, g_{b t}^{a}\right)} X \frac{1+\overrightarrow{D_{t+1}^{a}}\left(x_{t+1}^{a}, y_{t+1}^{a}, b_{t+1}^{a} ; g_{y t+1}^{a}, g_{b t+1}^{a}\right)}{1+\bar{D}_{t}^{a}\left(x_{t+1}^{a}, y_{t+1}^{a}, b_{t+1}^{a} ; g_{y t+1}^{a}, g_{b t+1}^{a}\right)}\right]^{1 / 2}$

The simplified expression is thus;

$$
G M L P I_{t, t+1}=E C_{t, t+1}^{a} \times T C_{t, t+1}^{a}
$$

Where $E C^{a}$ and $T C^{a}$ represent efficiency change and technical change measured on the basis of the groupfrontier, respectively.

Similarly, assuming that all of $a$ technology sets are subset of a common metatechnology set $P^{*}$, I define the directional output distance function of metafrontier in the base period $t$ as:

$$
\overrightarrow{D_{t}^{*}}\left(x_{t}^{*}, y_{t}^{*}, b_{t}^{*} ; g_{y t}^{*}, g_{b t}^{*}\right)=\sup \left\{\beta_{t}^{*}:\left(x_{t}^{*}, y_{t}^{*}+\beta_{t}^{*} g_{y t}^{*}, b_{t}^{*}+\beta_{t}^{*} g_{b t}^{*}\right) \in P_{t}^{*}\left(x_{t}^{*}\right)\right\}
$$

The metafrontier Malmquist Luenberger Productivity Index (MMLPI) is thus:

$$
M M L P I_{t, t+1}=\left\{\frac{1 /\left[1+\overrightarrow{D_{t}^{*}}\left(x_{t+1}^{*}, y_{t+1}^{*}, b_{t+1}^{*} ; g_{y t+1}^{*}, g_{b t+1}^{*}\right)\right]}{1 /\left[1+\overrightarrow{D_{t}^{*}}\left(x_{t}^{*}, y_{t}^{*}, b_{t}^{*} ; g_{y t}^{*}, g_{b t}^{*}\right)\right]} X \frac{1 /\left[1+\overrightarrow{D_{t+1}^{*}}\left(x_{t+1}^{*}, y_{t+1}^{*}, b_{t+1}^{*} ; g_{y t+1}^{*}, g_{b t+1}^{*}\right)\right]}{1 /\left[1+\overrightarrow{D_{t+1}^{*}}\left(x_{t}^{*}, y_{t}^{*}, b_{t}^{*} ; g_{y t}^{*}, g_{b t}^{*}\right)\right]}\right\}^{1 / 2}
$$

Similar to Eq. (7) and (8), Eq. (10) can also be further decomposed into two components, one measuring efficiency change $\left(E C^{*}\right)$ and one accounting for technical change $T C^{*}$. These are:

$$
\begin{gathered}
E C_{t, t+1}^{*}=\frac{1+\overrightarrow{D_{t}^{*}}\left(x_{t}^{*}, y_{t}^{*}, b_{t}^{*} ; g_{y t}^{*}, g_{b t}^{*}\right)}{1+\overrightarrow{D_{t+1}^{*}}\left(x_{t+1}^{*}, y_{t+1}^{*}, b_{t+1}^{*} ; g_{y t+1}^{*}, g_{b t+1}^{*}\right)} \\
T C_{t, t+1}^{*}=\left[\frac{1+\overrightarrow{D_{t+1}^{*}}\left(x_{t}^{*}, y_{t}^{*}, b_{t}^{*} ; g_{y t}^{*}, g_{t}^{*}\right)}{1+\overrightarrow{D_{t}^{*}}\left(x_{t}^{*}, y_{t}^{*}, b_{t}^{*} ; g_{y t}^{*}, g_{b t}^{*}\right)} X \frac{1+\overrightarrow{D_{t+1}^{*}}\left(x_{t+1}^{*}, y_{t+1}^{*}, b_{t+1}^{*} ; g_{t t+1}^{*}, g_{b t+1}^{*}\right)}{1+\overrightarrow{D_{t}^{*}}\left(x_{t+1}^{*}, y_{t+1}^{*}, b_{t+1}^{*} ; g_{y t+1}^{*}, g_{b t+1}^{*}\right)}\right]^{1 / 2}
\end{gathered}
$$

The simplified version of Eq. (11) is therefore:

$$
M M L P I_{t, t+1}=E C_{t, t+1}^{*} \times T C_{t, t+1}^{*}
$$

Where $E C^{*}$ and $T C^{*}$ correspond to the efficiency change and technical change relative to the metafrontier, respectively. 
I then follow Chen \& Ynag (2011), and rearrange the Eq. (10) to obtain technology gap ratio change (TGRC) as follows:

$$
M M L P I_{t, t+1}=E C_{t, t+1}^{a} X T C_{t, t+1}^{a} X T G R C_{t, t+1}^{a}
$$

Substituting Eq. (8) into Eq. (14), I obtain:

$$
M M L P I_{t, t+1}=G M L P I_{t, t+1} X T G R C_{t, t+1}^{a}
$$

thus,

$$
T G R C_{t, t+1}^{a}=\frac{M M L P I_{t, t+1}}{G M L P I_{t, t+1}}
$$

TGRC measures the technology gap between the current and potential technology levels in two time periods (Oh \& Lee, 2010). However, it provides only the information on the changes in technology leadership. For detailed analysis of the innovative DMUs, I follow Chen \& Ynag (2011) and decompose the TGRC in Eq. (16) into pure technological catch-up (PTCU) and frontier catch-up (FCU) as follows:

$$
T G R C_{t, t+1}^{a}=\underbrace{\frac{T G R_{t+1}^{a}\left(x_{t+1}, y_{t+1}\right)}{T G R_{t}^{a}\left(x_{t}, y_{t}\right)}} X[\underbrace{\frac{T G R_{t}^{a}\left(x_{t+1}, y_{t+1}\right)}{T_{t+1}^{a}\left(x_{t+1}, y_{t+1}\right)} X \frac{T G R_{t}^{a}\left(x_{t}, y_{t}\right)}{T G R_{t+1}^{a}\left(x_{t}, y_{t}\right)}}]^{1 / 2}
$$

PTCU

FCU

PTCU denotes the shrinkage degree of technology gap, i.e. an increase in technology gap ratio. A value larger than unity indicates the shrinkage of the technology gap between the current and potential technology. FCU, on the other hand, captures the velocity of frontier-shift between groupfrontier and metafrontier. The value of FCU is larger than unity when the metafrontier shift is faster than that of the groupfrontier, suggesting an increase in room for potential technological progress (Chen, 2012) and this value is less than unity when there is frontier catch-up (Li \& Lin, 2015).

Parametric stochastic frontier analysis (SFA) and non-parametric DEA are the most commonly used techniques to compute the distance functions. In this study, I use the DEA to compute the directional distance functions of MMLPI and GMLPI. Following Juo et al. (2015), eight different linear programming problems (LPs) are solved. See Chung et al (1997), Färe et al. (2007) and Juo et al. (2015) for more details on LPs. 


\section{Data and variables}

This section provides information on the construction of my sample and defines the input and output variables used in the analysis.

I use data from the Microfinance Information Exchange (MIX) network (www.mixmarket.org), the largest microfinance database available to the public. MIX provides high quality information about more than 800 MFIs worldwide (Servin et al., 2012). Financial and social information available in MIX have been used in a number of studies (e.g., Gutierrez-Niéto et al., 2009; Ahlin et al., 2011; Hermes et al., 2011; Servin et al., 2012; Louis et al., 2013). I collected a balance panel data for the period 2005-2011 from 298 MFIs across the world. NGOs are the most common form of ownership in my sample (121), followed by NBFIs (113), banks (47) and cooperatives (17). The sample period captures the variations of the MFIs productivity in the run up to the crisis (2005-2007), throughout the crisis (2007-2008) and the post crisis period (20082011). All financial data are measured in US\$, unless otherwise stated.

The literature generally applies two approaches to estimate the efficiency and productivity dynamics of financial institutions: the production approach (Benston, 1965) and the intermediation approach (Sealey \& Lindley, 1977). Under the production approach, financial institutions are defined as production units that produce services for their customers by using resources such as capital and labor. The intermediation approach views the financial institutions as intermediaries that employ labor, deposits and physical capital to produce loans and investments. Use of the intermediation approach is, however, not appropriate in the context of microfinance as most MFIs across the world are not deposit-taking institutions (Galema et al., 2011; Servin et al., 2012; Wijesiri et al., 2015). Thus, for my definitions of inputs and outputs for the distance function, I employ the production approach where MFIs are considered as production units that produce services for their customers by using resources such as labor, technology, materials and the associated costs. It is also worth noting that with a few exceptions, most empirical studies of MFI efficiency (e.g., Gutierrez-Niéto et al., 2009; Hartarska \& Mersland, 2012; Wijesiri et al., 2015) take place under strong modelling assumption. These studies define two models: one financial one and the other social. However, despite the fact that both models use the same input variables, they implicitly assume that all the inputs are devoted to the production of either financial or social outputs. However, in the real world, it is only a 
share of these inputs that are devoted to the production of both financial and social outputs. Thus, results derived based on this modelling assumption can be biased. In this study, I relax this assumption. I assume that an MFI, irrespective of its ownership type, uses inputs for producing both types of outputs simultaneously and not just one type. I select input and output variables based on my prior knowledge of literature on MFI efficiency (e.g., Nghiem et al., 2006; Gutiérrez-Nieto et al., 2009; Piot-Lepetit \& Nzongang, 2014; Wijesiri et al., 2015) and data availability. I chose three input and four output variables. The input variables contain total assets, operating expenses and number of employees. On the other hand, I use both desirable and undesirable outputs in the production process. The main consideration that guided my selection of the output measures is the dual mission of microfinance programs: financial sustainability and poverty outreach. Gross loan portfolio (GLP), financial revenue, average loan balance to GNP per capita (ALB) and number of active borrowers (ACTB) are defined as desirable outputs and NPLs- as undesirable output. While GLP, financial revenue and NPLs acknowledge the financial aspects, ALB and ACTB capture the MFIs' outreach objectives (measures of 'depth' and 'breadth' of outreach, respectively). Dividing average loan balance per borrower by the per capita GNP accounts for the differences in currency and purchasing power across countries. A number of studies on bank efficiency (e.g., Park \& Weber, 2006; Fujii et al., 2014; Zha et al., 2015) employ NPLs as undesirable by-products of the loan process because of their direct negative impact on the efficiency estimates. In the present study, I take the dollar value of loans that are 30 days past due as a proxy for NPLs. Table 1 recapitulates the descriptive statistics of input and output variables used in this study by ownership type over the period 2005-2011. The relatively high standard deviation values indicate that MFIs in my sample vary greatly with respect to their input usage and output production.

Table 1

Summary statistics (2005-2011)

\begin{tabular}{|c|c|c|c|c|c|c|c|c|c|c|c|c|c|c|}
\hline \multirow{2}{*}{ Variables } & \multicolumn{2}{|c|}{2005} & \multicolumn{2}{|c|}{2006} & \multicolumn{2}{|c|}{2007} & \multicolumn{2}{|c|}{2008} & \multicolumn{2}{|c|}{2009} & \multicolumn{2}{|c|}{2010} & \multicolumn{2}{|c|}{2011} \\
\hline & Mean & $\begin{array}{l}\text { Std. } \\
\text { Dev. }\end{array}$ & Mean & $\begin{array}{l}\text { Std. } \\
\text { Dev. }\end{array}$ & Mean & $\begin{array}{l}\text { Std. } \\
\text { Dev. }\end{array}$ & Mean & $\begin{array}{l}\text { Std. } \\
\text { Dev. }\end{array}$ & Mean & $\begin{array}{l}\text { Std. } \\
\text { Dev. }\end{array}$ & Mean & $\begin{array}{l}\text { Std. } \\
\text { Dev. }\end{array}$ & Mean & $\begin{array}{l}\text { Std. } \\
\text { Dev. }\end{array}$ \\
\hline \multicolumn{15}{|l|}{ Inputs } \\
\hline \multicolumn{15}{|c|}{ Assets ('000 US\$) } \\
\hline Banks & 79,544 & 111,319 & 115,980 & 152,687 & 177,777 & 218,657 & 226,767 & 275,098 & 271,796 & 349,211 & 330,668 & 448,134 & 393,419 & 529,335 \\
\hline Cooperatives & 19,224 & 28,519 & 29,575 & 47,505 & 42,269 & 72,073 & 43,731 & 66,414 & 66,451 & 117,002 & 77,234 & 140,474 & 88,410 & 153,150 \\
\hline NBFIs & 24,392 & 48,169 & 33,182 & 59,025 & 47,707 & 72,170 & 62,028 & 90,344 & 85,944 & 13,341 & 100,717 & 173,456 & 111,934 & 205,513 \\
\hline
\end{tabular}




\begin{tabular}{|c|c|c|c|c|c|c|c|c|c|c|c|c|c|c|}
\hline NGOs & 9,060 & 28,736 & 13,171 & 40,223 & 17,883 & 51,642 & 20,916 & 58,992 & 24,427 & 67,200 & 28,194 & 75,143 & 32,446 & 81,170 \\
\hline \multicolumn{15}{|c|}{ OE ('000 US\$) } \\
\hline Banks & 10,042 & 13,662 & 13,704 & 17,818 & 19,469 & 25,663 & 25,059 & 33,176 & 26,971 & 36,762 & 32,013 & 47,794 & 38,291 & 56,039 \\
\hline Cooperatives & 1,621 & 2,071 & 2,681 & 4,073 & 3,452 & 5,392 & 4,119 & 6,596 & 5,473 & 9,482 & 5,608 & 8,941 & 6,843 & 10,731 \\
\hline NBFIs & 3,143 & 7,270 & 3,981 & 8,255 & 5,410 & 9,362 & 7,248 & 10,808 & 9,110 & 1,515 & 10,910 & 19,099 & 11,984 & 21,107 \\
\hline NGOs & 1,201 & 2,366 & 1,670 & 3,581 & 2,403 & 5,005 & 2,970 & 7,260 & 3,016 & 6,613 & 3,701 & 7,518 & 4,371 & 7,826 \\
\hline \multicolumn{15}{|l|}{ Employees } \\
\hline Banks & 847 & 2,351 & 1,112 & 3,042 & 1,415 & 3,699 & 1,638 & 3,639 & 1,693 & 3,575 & 1,796 & 3,564 & 1,976 & 3,763 \\
\hline Cooperatives & 83 & 95 & 104 & 133 & 133 & 175 & 164 & 219 & 185 & 251 & 206 & 284 & 223 & 295 \\
\hline NBFIs & 239 & 446 & 291 & 487 & 382 & 594 & 524 & 925 & 678 & 134 & 806 & 1,734 & 763 & 1,414 \\
\hline NGOs & 298 & 1,385 & 396 & 1,761 & 511 & 2,351 & 531 & 2,130 & 586 & 2,299 & 624 & 2,218 & 655 & 2,169 \\
\hline \multicolumn{15}{|c|}{ Desirable Outputs } \\
\hline \multicolumn{15}{|c|}{ GLP ('000 US\$) } \\
\hline Banks & 57,051 & 79,755 & 81,199 & 105,187 & 124,351 & 144,775 & 160,519 & 185,998 & 185,408 & 237,992 & 227,424 & 295,781 & 280,850 & 365,531 \\
\hline Cooperatives & 14,795 & 21,233 & 22,076 & 34,890 & 31,512 & 53,556 & 32,948 & 48,020 & 44,793 & 76,603 & 58,437 & 106,129 & 67,118 & 112,403 \\
\hline NBFIs & 19,482 & 38,842 & 26,846 & 47,201 & 39,569 & 59,082 & 53,483 & 79,655 & 71,459 & 11,782 & 84,505 & 151,727 & 95,717 & 180,722 \\
\hline NGOs & 7,205 & 24,657 & 10,567 & 34,451 & 14,359 & 43,570 & 17,210 & 52,599 & 18,903 & 53,725 & 22,234 & 59,174 & 25,221 & 64,922 \\
\hline \multicolumn{15}{|l|}{ ALB } \\
\hline Banks & 1.2318 & 1.6543 & 1.2585 & 2.1204 & 1.2820 & 1.5911 & 1.2139 & 1.3723 & 1.1565 & 1.1741 & 1.3227 & 1.4033 & 1.3395 & 1.3729 \\
\hline Cooperatives & 0.5015 & 0.3938 & 0.5590 & 0.4422 & 0.6406 & 0.5355 & 0.6048 & 0.4676 & 0.6097 & 0.4536 & 0.6100 & 0.4400 & 0.6492 & 0.4366 \\
\hline NBFIs & 0.5196 & 0.5147 & 0.5332 & 0.4841 & 0.5672 & 0.5309 & 0.5420 & 0.5471 & 0.4729 & 0.0349 & 0.4830 & 0.4677 & 0.4876 & 0.4650 \\
\hline NGOs & 0.2998 & 0.4470 & 0.3210 & 0.5715 & 0.3769 & 0.8528 & 0.3554 & 0.8262 & 0.3630 & 1.0042 & 0.3288 & 0.7144 & 0.2865 & 0.4431 \\
\hline \multicolumn{15}{|c|}{ FR ('000 US\$) } \\
\hline Banks & 20,071 & 30,191 & 28,377 & 42,076 & 40,195 & 58,173 & 53,268 & 73,776 & 57,286 & 84,626 & 68,502 & 111,186 & 81,738 & 124,919 \\
\hline Cooperatives & 2,901 & 3,765 & 4,359 & 6,304 & 5,827 & 8,669 & 7,130 & 10,575 & 10,429 & 18,820 & 10,409 & 16,613 & 13,125 & 20,493 \\
\hline NBFIs & 6,464 & 14,981 & 8,184 & 17,119 & 11,516 & 18,730 & 16,314 & 24,631 & 21,473 & 3,704 & 24,636 & 46,227 & 25,219 & 52,658 \\
\hline NGOs & 2,283 & 7,086 & 3,199 & 9,269 & 4,286 & 10,573 & 5,104 & 12,341 & 5,498 & 13,278 & 6,521 & 15,525 & 7,995 & 19,085 \\
\hline \multicolumn{15}{|l|}{ ACTB } \\
\hline Banks & 164,166 & 732,575 & 199,857 & 864,938 & 224,819 & 895,917 & 252,087 & 908,537 & 271,346 & 950,378 & 289,202 & 990,649 & 314,212 & $1,005,777$ \\
\hline Cooperatives & 15,525 & 23,789 & 17,414 & 25,025 & 18,712 & 22,446 & 19,659 & 23,056 & 20,429 & 22,803 & 21,910 & 24,003 & 23,811 & 27,451 \\
\hline NBFIs & 46,344 & 117,842 & 59,506 & 140,986 & 78,205 & 186,490 & 110,361 & 311,117 & 156,459 & 483,328 & 183,723 & 587,638 & 164,414 & 519,811 \\
\hline NGOs & 63,242 & 381,969 & 80,863 & 472,796 & 92,447 & 498,276 & 104,725 & 542,117 & 96,757 & 387,328 & 109,472 & 434,220 & 109,127 & 419,913 \\
\hline \multicolumn{15}{|c|}{ Undesirable Outputs } \\
\hline \multicolumn{15}{|c|}{ NPL ('000 US\$) } \\
\hline Banks & 2,271 & 5,578 & 2,576 & 5,520 & 2,602 & 4,734 & 5,081 & 9,431 & 11,257 & 24,614 & 10,958 & 19,594 & 11,573 & 21,404 \\
\hline Cooperatives & 881 & 1,254 & 984 & 1,402 & 1,479 & 2,126 & 2,261 & 4,416 & 2,391 & 3,892 & 2,899 & 5,452 & 3,828 & 8,835 \\
\hline NBFIs & 1,009 & 3,072 & 1,409 & 3,444 & 1,468 & 3,062 & 1,866 & 3,996 & 5,217 & 1,601 & 12,329 & 44,731 & 10,336 & 36,003 \\
\hline NGOs & 219 & 463 & 306 & 645 & 466 & 1,314 & 674 & 2,249 & 923 & 2,877 & 1,378 & 5,582 & 1,326 & 4,744 \\
\hline
\end{tabular}




\section{Empirical results}

The empirical analysis is summarized in two sections. I first illustrate the estimated MLPI and its components for metafrontier and groupfrontiers. Then, in the second section, I discuss the empirical implications.

\subsection{Productivity analysis}

I computed productivity estimates for all ownership types for 2005-2011, using the method described previously. Table 2 presents the average annual estimates for the risk-adjusted MLPI and its decompositions with respect to the metafrontier and group-specific frontiers. The first three columns of the table show MMLPI, $E C^{*}$ and $T C^{*}$. The next three columns report the GMPLI, $E C^{a}$ and $T C^{a}$. For MMLPI and GMPLI (and their components), a value greater than unity indicates a progression while a value less than unity indicates a regression. A value equal to unity implies no change in the performance measure being referred to. The last column provides average values of PTCU and FCU. PTCU denotes the growth gap of technical efficiency between the current technology and the potential technology. A value larger than unity indicates the shrinkage of the technology gap. On the other hand, FCU measures the convergence (or divergence) of current technology to potential technology in two time periods. It sheds light on the changes in technological leadership dynamics among different groups (Casu et al., 2013). A value larger than unity indicates a large progress in the metafrontier than that in the groupfrontier. When this value is less than unity, then there is frontier catch-up (Li \& Lin, 2015). It is also instructive to note that the use of group frontier productivity measures for comparison is not appropriate as they are gauged using distinct bases (see Chen \& Yang, 2011). Thus, I use the metafrontier as the evaluation basis when comparing the productivity growth of MFIs with different ownership status.

During the pre-crisis period all ownership types, except cooperatives, show productivity growth, albeit at different levels. Results for 2007, show that banks had the highest potential productivity growth $(24.97 \%)$, followed by NBFIs $(7.78 \%)$. The highest productivity growth in banks is mainly attributable to the increase in their group-specific technology (46.07\%) and higher catchup dynamics $(1.15 \%)$ while the improvement of productivity in NBFIs is due to a positive contribution of their group-specific efficiency (2.54\%), technology (7.29\%) and relatively higher catch-up dynamics. On the other hand, although cooperatives exhibit productivity regression in 
$2006(-0.15 \%)$, their average potential productivity $(6.63 \%)$ improved in the following year. This productivity growth is mainly attributable to the improvement of their group-specific efficiency (0.01\%), technology (6.09\%) and catch-up dynamics. NGOs show the lowest productivity growth immediately before the crisis (.067\%), mainly due to the weak improvement of their group-specific efficiency $(0.47 \%)$ and convergence of the technology used by them towards the potential technology. This finding is interesting because all types of ownership show technological innovations except for NGOs that experience technological regression in 2007. The relatively higher technological progress of banks followed by NBFIs is not surprising due to their links with local and foreign capital markets and hence they can benefit from technological spillovers. Examining the productivity growth patterns of microfinance ownership types in the 2008 crisis, it is observed that the impact of crisis on MFI productivity is not uniform across microfinance ownerships. While banks and NBFIs show a clear downward trend in productivity growth, the reverse holds for the other ownership types. It is apparent from Table 2 that the banks' productivity deterioration $(-0.01 \%)$ is mainly due to the regression of their group-specific technology (-1.49\%) and expansion of the technology gap as shown by PTCU and FCU values together. On the other hand the lower productivity gain of NBFIs $(0.41 \%)$ is the result of a slight increase in their group-specific technology $(3.16 \%)$ and shrinkage of the technology gap. The productivity dynamics of non-shareholding ownerships during the crisis seem to be more immune to the effects of the crisis. Though cooperatives and NGOs show an opposite trend, they both reach almost similar productivity levels by 2008 . As can be seen from Table 2, results show that productivity growth in cooperatives drops from $6.63 \%$ in 2007 to $1.37 \%$ during the 2008 crisis mainly due to the absence of catch-up dynamics while the productivity of NGOs improves slightly from $0.067 \%$ in 2007 to $1.39 \%$ during the 2008 crisis. For NGOs, the slight productivity improvement during the crisis is mainly attributable to an increases in their group-specific technology $(2.33 \%)$. However, like cooperatives, productivity growth of NGOs seems to be retarded by their poor dynamics for catching-up with the potential technology. The picture is totally different in 2009 , one year after the crisis. While productivity growth of all ownership types drop, banks' productivity drops the most. Moreover, from the analysis of Table 2, I notice that different ownership forms exhibit different sources of productivity change. While the productivity drop in banks (-6.73\%) comes from the decline in their group-specific technology ($3.75 \%)$ and absence of catch-up dynamics, the productivity decline in NBFIs $(-4.72 \%)$ is caused 
by the regression of their group-specific efficiency $(-2.17 \%)$, technology $(-3.69 \%)$ and absence of catch-up dynamics. Moreover, the productivity decline of cooperatives $(-2.55 \%)$ is the consequence not only of the reduction in their group-specific efficiency $(-0.91 \%)$ but also because they have made no progress in catch-up dynamics as indicated by PTCU and FCU values together. NGOs show the lowest productivity decline $(-1.72 \%)$, mainly due to the deterioration of their group-specific technology (-5.05\%) and absence of catch-up dynamics. It is interesting to observe that productivity declined all ownership types in 2009 are driven by the lack of progression in their catch-up dynamics, as indicated by average PTCU and FCU values. Two years after the crisis, it is observed that all ownerships with the exception of NBFIs show productivity growth. Cooperatives exhibit the highest productivity growth (6.91\%), followed by banks (4.06\%) and NGOs (2.74\%). The improvement in productivity of banks and NGOs is due to the improvement of their group-specific efficiency $(0.25 \%, 0.65 \%)$, technology $(2.81 \%$, $2.92 \%$ ) and weak catch-up dynamics. The highest productivity growth of cooperatives is due to the increase of their group-specific efficiency (1.08\%), technology (1.01\%) and shrinkage of their technology gap. On the other hand, the PTCU and FCU values together exhibit the lack of catch-up dynamics of NBFIs that severely affect their productivity regression $(-0.87 \%)$ in 2010. In the most recent year (2011), among four ownership types, productivity growth of banks (7.47\%) outperforms those of the other ownership types (3.41\% for cooperatives, $5.11 \%$ for NBFIs and $0.28 \%$ for NGOs). This productivity performance of banks results from an increase in their group-specific technology (4.19\%) and weak catch-up dynamics. Moreover, the improved productivity of cooperatives is mostly due to the increase in their group-specific technology (4.38\%) and weak catch-up dynamics while productivity growth in NBFIs is driven by the increase in their group-specific efficiency $(0.45 \%)$, technology $(5.89 \%)$ and weak catch-up dynamics. Productivity decline in NGOs, on the other hand, is caused by regression of their group-specific efficiency (-.8\%) despite weak catch-up dynamics. Note that the average PTCU and FCU values of all ownership types demonstrate that technology adopted by each ownership type converges towards potential technology exhibiting catch-up dynamics by 2011 .

Table 2

Decomposition of Metafrontier Malmquist Luenberger Productivity Index

\begin{tabular}{cccccccccc}
\hline $\begin{array}{c}\text { Ownership } \\
\text { Type }\end{array}$ & Period & MMLPI & EC $^{*}$ & TC $^{*}$ & GMLPI & $E C^{\mathrm{a}}$ & TC $^{\mathrm{a}}$ & PTCU & FCU \\
\hline
\end{tabular}




\begin{tabular}{|c|c|c|c|c|c|c|c|c|c|}
\hline \multirow[t]{6}{*}{ Bank } & $2005 / 2006$ & 1.0326 & 1.0131 & 1.0209 & 1.0410 & 0.9948 & 1.0459 & 1.0213 & 0.9921 \\
\hline & $2006 / 2007$ & 1.2497 & 0.9902 & 1.2590 & 1.4354 & 0.9842 & 1.4607 & 1.0115 & 1.0295 \\
\hline & $2007 / 2008$ & 0.9999 & 1.0283 & 0.9761 & 1.0211 & 1.0477 & 0.9851 & 0.9898 & 1.0189 \\
\hline & $2008 / 2009$ & 0.9327 & 0.9835 & 0.9537 & 0.9684 & 1.0115 & 0.9625 & 0.9706 & 1.0475 \\
\hline & $2009 / 2010$ & 1.0406 & 1.0556 & 0.9894 & 1.0311 & 1.0025 & 1.0281 & 1.0552 & 0.9775 \\
\hline & $2010 / 2011$ & 1.0747 & 1.0419 & 1.0342 & 1.0402 & 0.9986 & 1.0419 & 1.0436 & 0.9979 \\
\hline \multirow[t]{6}{*}{ Cooperative } & $2005 / 2006$ & 0.9985 & 0.9671 & 1.0332 & 1.0131 & 1.0062 & 1.0072 & 0.9611 & 1.0396 \\
\hline & $2006 / 2007$ & 1.0663 & 1.0341 & 1.0322 & 1.0610 & 1.0001 & 1.0609 & 1.0340 & 0.9998 \\
\hline & $2007 / 2008$ & 1.0137 & 0.9926 & 1.0211 & 0.9778 & 0.9992 & 0.9785 & 0.9933 & 1.0528 \\
\hline & $2008 / 2009$ & 0.9745 & 0.9807 & 0.9896 & 0.9917 & 0.9909 & 1.0007 & 0.9899 & 1.0280 \\
\hline & $2009 / 2010$ & 1.0691 & 1.0420 & 1.0274 & 1.0203 & 1.0108 & 1.0101 & 1.0316 & 1.0415 \\
\hline & $2010 / 2011$ & 1.0341 & 1.0243 & 1.0098 & 1.0384 & 0.9951 & 1.0438 & 1.0298 & 0.9770 \\
\hline \multirow[t]{6}{*}{ NBFI } & $2005 / 2006$ & 1.0122 & 0.9943 & 1.0181 & 1.0152 & 0.9995 & 1.0155 & 0.9948 & 1.0051 \\
\hline & $2006 / 2007$ & 1.0778 & 1.0543 & 1.0259 & 1.0995 & 1.0254 & 1.0729 & 1.0274 & 0.9673 \\
\hline & $2007 / 2008$ & 1.0041 & 0.9814 & 1.0229 & 1.0090 & 0.9787 & 1.0316 & 1.0027 & 1.0682 \\
\hline & $2008 / 2009$ & 0.9528 & 0.9728 & 0.9757 & 0.9457 & 0.9783 & 0.9631 & 0.9948 & 1.0224 \\
\hline & $2009 / 2010$ & 0.9913 & 1.0146 & 0.9782 & 1.0346 & 1.0208 & 1.0136 & 0.9949 & 1.0002 \\
\hline & $2010 / 2011$ & 1.0511 & 1.0230 & 1.0278 & 1.0630 & 1.0045 & 1.0589 & 1.0194 & 0.9747 \\
\hline \multirow[t]{6}{*}{ NGO } & $2005 / 2006$ & 1.0019 & 1.0083 & 0.9946 & 1.0128 & 1.0184 & 0.9963 & 0.9924 & 1.0099 \\
\hline & $2006 / 2007$ & 1.0067 & 1.0441 & 0.9658 & 0.9926 & 1.0047 & 0.9887 & 1.0415 & 0.9937 \\
\hline & $2007 / 2008$ & 1.0139 & 0.9602 & 1.0561 & 1.0088 & 0.9870 & 1.0233 & 0.9735 & 1.0459 \\
\hline & $2008 / 2009$ & 0.9564 & 0.9828 & 0.9736 & 0.9536 & 1.0034 & 0.9495 & 0.9797 & 1.0362 \\
\hline & $2009 / 2010$ & 1.0274 & 1.0541 & 0.9757 & 1.0358 & 1.0065 & 1.0292 & 1.0477 & 0.9562 \\
\hline & $2010 / 2011$ & 0.9972 & 1.0009 & 0.9970 & 0.9958 & 0.9920 & 1.0041 & 1.0102 & 0.9975 \\
\hline
\end{tabular}

\subsection{Empirical implications}

Figure 1 graphs the average potential productivity growth of all ownership types over time. It provides further insight into the empirical findings discussed above. As in Ivashina \& Scharfstein (2010), I divided the crisis period into two phases: Crisis I (August, 2007-July, 2008) and Crisis II (August, 2008-December, 2008). These subdivisions enabled me to provide a comprehensive assessment of the impact of crisis on different microfinance ownership structures. Note that the two vertical lines extending up from the x-axis of Figure 1 represent crisis I and II.

When average potential productivity measures from Table 2 are plotted over time, they show a potential productivity growth of banks and NBFIs at a high level during the last phase of the credit boom, and experiencing a declining trend during the peak crisis period. This trend is more noticeable for banks. The productivity growth pattern of banks and NBFIs could be explained by the regulatory and funding framework of both ownership types. Being regulated entities, banks and NBFIs are allowed to collect deposits. Apart from deposits as a source of loanable funds, 
both ownership types can easily access national and international capital markets. In addition to the high level of savings mobilization, a massive increase of international investments on microfinance during the boom period (Deutsche Bank Research, 2007; Tchuigoua, 2014), may have improved the productivity of both ownership types. Moreover, technological spillovers may have stimulated both shareholding ownership types to converge towards the best technology during the pre-crisis period and increase the scale of their operations. Nevertheless, Littlefield \& Kneiding (2009) reveal that after the crisis unfolded a number of regulated financial institutions experienced a considerable deposit withdrawal due to the loss of clients' confidence in financial institutions, which is largely a matter of trust. This may have severely influenced banks' poor performance during the crisis as shown in Figure 1, because they form a large part of their capital base through savings mobilization. In addition to the massive outflow of deposits that may have led to a severe liquidity crunch, political pressure to support preferential clients, raising substantial subsidized loans for politically motivated projects and political appointments of illqualified individuals on the boards of state-owned banks may have triggered the poor performance of banks during the distress period. Although NBFIs are unlikely to be amenable to such political interventions, a substantial outflow of deposits and a decline in foreign investments may have had an adverse effect their performance in the 2008 crisis. Moreover, as shown in Figure 1, the banks' productivity decline is faster than that for NBFIs during the crisis and early post-crisis periods, but the opposite is true in 2010, when the banks' average productivity growth exceeds that for NBFIs. Banks show signs of recovery in the last phase of the post-crisis period because they may have pursued appropriate strategic reforms introduced by regulators and some of them may even have accessed financial support from central banking authorities or their parent banks to recover from their liquidity problems. However, the question which then arises is why the recovery remains very weak in NBFIs two years after the eruption of the crisis, even though they may also be exposed to similar fiscal reforms as banks. A likely explanation for the slump of NBFIs' productivity in 2010 is the continuing funding constraint they faced due to loss of external financial support from investors and other commercial financial sources that were severely hit by the crisis. The situation may have been further exacerbated by the withdrawal of deposits by their clients. In fact, during the post crisis period NBFIs may have been at a competitive disadvantage in terms of obtaining clients' confidence compared with banks which may have had better access to government safety net programs. Thus, a large number of clients 
may have withdrawn their deposits from NBFIs during the post crisis period. Moreover, given the very weak catch-up dynamics exhibited by NBFIs compared to the banks as discussed earlier, NBFIs' poor performance in 2010 is unsurprising. The persistent poor performance of NBFIs implies that although banks may restructure their operating and governance mechanisms quickly in response to the new financial reforms, NBFIs may fail to adopt the best available technology or perhaps fail to appropriately utilize the chosen technologies quickly enough. This finding is also consistent with the finding of banking literature (e.g, Leightner \& Lovell, 1998; Isik \& Hassan, 2003; Casu et al., 2013) which shows that different ownership forms react at different speeds to changes in the regulatory environment. Most likely, these NBFIs have been transformed from NGOs and have deviated from their poverty outreach objectives for the sake of profit maximization and become an increasingly attractive investment opportunity for commercial institutions and private investors. Although their risky bets in the capital market achieve many benefits for NBFIs particularly in terms of increased profits and technological spilovers during the pre-crisis credit boom period, their performance can turn sour with the failure of the capital market. Moreover, the finding of downward productivity trends of banks and NBFIs during the post crisis period is further supported by the plot of NPLs (000' US\$) against the time period provided in Figure 2. As shown in Figure 2, NPLs for banks and NBFIs more than double during the post crisis period and peak one year after the crisis (2009) for banks and two years after the crisis (2010) for NBFIs. Thus, it would not be surprising to observe that banks and NBFIs experience poor performance as an increasing number of customer loans become nonperforming after the 2008 crisis. Both groups, nevertheless, exhibit similar patterns of productivity growth with improved productivity by 2011. Turning now to the productivity growth patterns of cooperatives and NGOs, it is clear from Figure 1 that both groups are less affected by the crisis than their shareholding competitors. Although both groups exhibit positive productivity growth in 2007, cooperatives demonstrate better performance than NGOs in terms of productivity improvement. Moreover, another interesting insight emerges from a comparison of productivity growth of NGOs and other ownership types in 2008. It seems that NGOs maintain a fairly steady pace of increasing productivity when the crisis hits. Cooperatives, on the other hand, show a downward trend in 2008. Yet, their productivity level is fairly similar to NGOs productivity level during the crisis. Thus, it is clear from the graph that both nonshareholding ownership types are relatively robust to the 2008 crisis. Caution is however advised 
in explaining the relatively better performance of cooperatives and NGOs in the crisis period. The stability of these ownership forms in the wake of crisis is not necessarily because of earning profits or their improved governance structure. Instead, it is more reasonable to attribute the stability of both non-regulated ownerships during the crisis to their limited exposure to 'toxic assets' and limited integration to commercial and cross-border financial sources. Because of their social orientation, they have fewer opportunities to raise funds through capital markets and private investors (Servin et al., 2012). Moreover, compared with shareholding ownerships, that often serve clients with larger businesses or small and medium enterprises (SMEs), and are more prone to macroeconomic shocks, recipients of non-shareholding ownerships, particularly NGOs, mainly from small-scale informal entrepreneurial ventures are unlikely to be hit by the crisis. Moreover, adherence to more conservative operating mechanisms, particularly use of the group lending model as well as the short-term lending cycles with weekly collecting meetings, may have positively contributed to their stability during the crisis. One year immediately after the crisis, productivity growth in cooperatives and NGOs, however, exhibit a downward trend as those of shareholding ownerships, but of less intensity. This may be attributable to the deteriorating of their portfolio quality as shown in Figure 2. Lack of financial support in terms of grants, subsidized loans or subsidized equity from donors and apex organizations may also be a reason for relatively poor performance of NGOs. However, productivity of both ownership types exhibits an upward trend by 2010. Relatively better performance of cooperatives during the post crisis period may be due to the fact that being member service organizations, they cater to people with a common bond, not necessarily the poor (Hamed, 2007) and often they tend to lend to less risky, middle-class salaried borrowers (Robinson, 2001). Thus, compared with shareholding ownerships, cooperatives seem to retain better asset quality over the period. Overall, Figure 1 demonstrates that, three years after the eruption of the crisis, productivity growth levels for banks, NBFIs and NGOs return close to or slightly higher than their early pre-crisis levels and cooperatives remain well above their pre-crisis average productivity levels. Moreover, technology adopted by all ownership types seem to converge towards potential technology by 2011, suggesting that monetary reforms introduced in the recent past facilitate a supportive environment for MFIs to adopt the best available technology. 


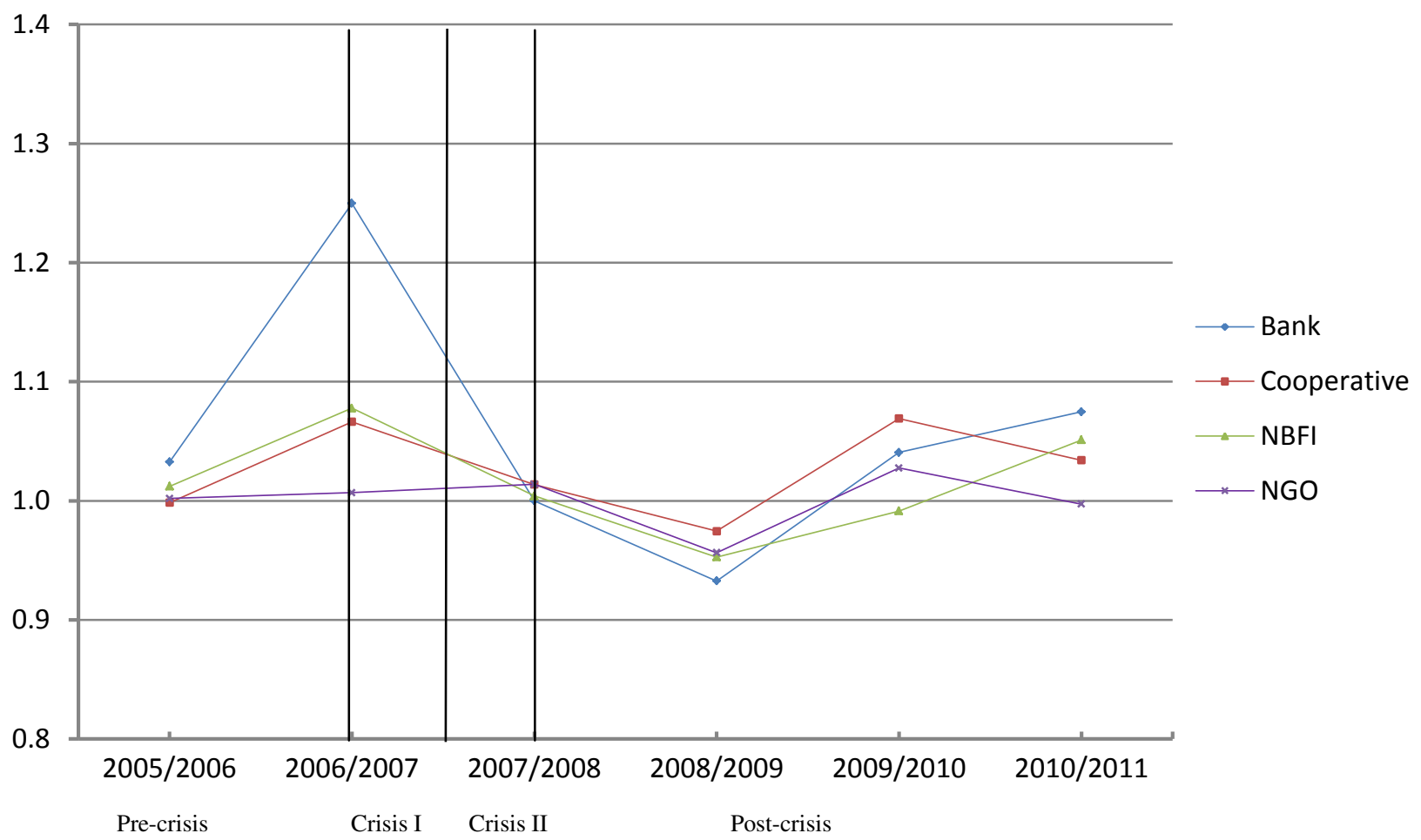

Fig. 1. Trends in MMLPI for the four microfinance ownership forms for the period 2006-2011.

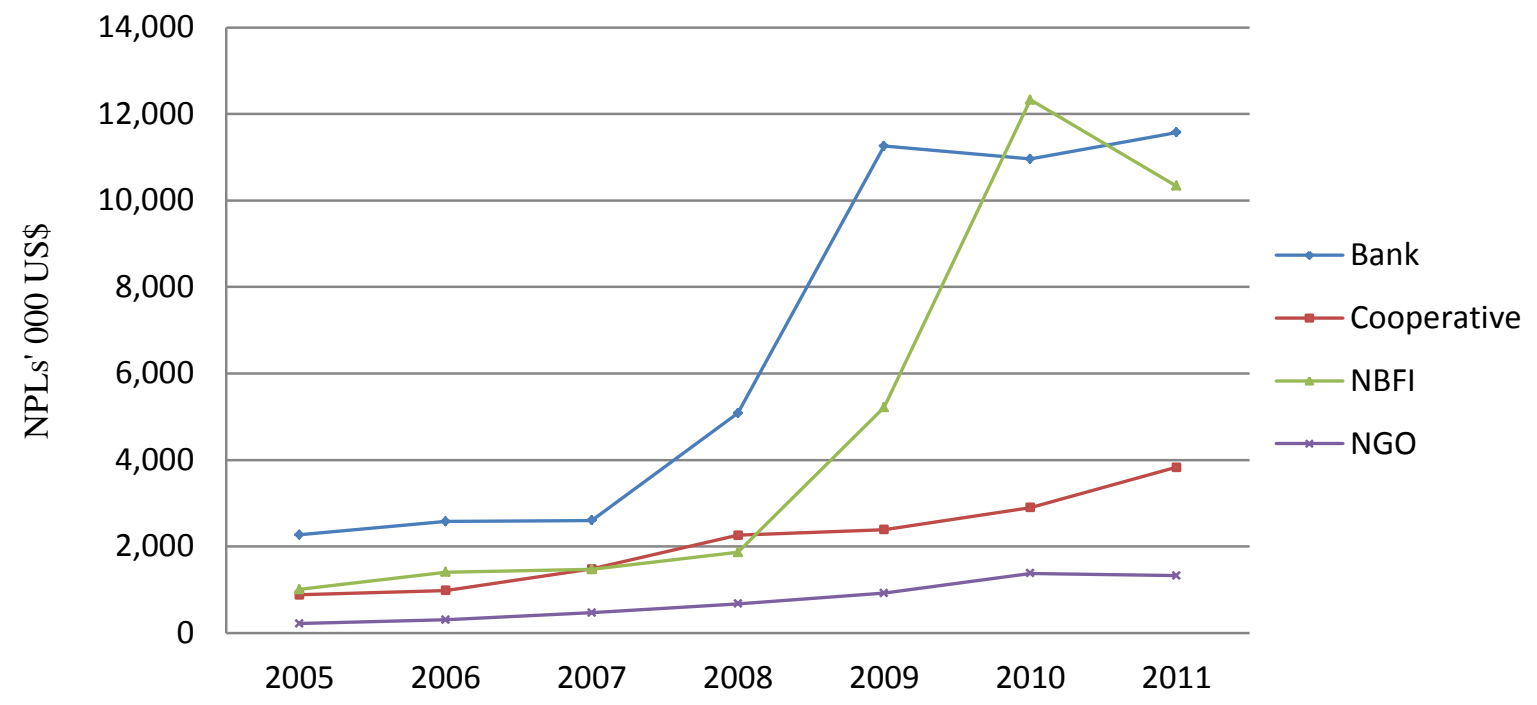

Fig. 2. Trends in NPLs (2005-2011)

\section{Conclusion}

In this paper, I investigate the effects of global financial crisis on the productivity dynamics of different microfinance ownership types. The analysis is based on the MLPI combined with the 
metafrontier concept. This method allows comparable productivity measures to be obtained for different microfinance ownership types in the presence of undesirable outputs. I find that the better performing ownerships in the crisis are the cooperatives and NGOs that often adhere to more conservative operating mechanisms and have less exposure to commercial funding sources and 'toxic assets'. On the other hand, shareholding ownership types performing better immediately before the crisis perform worse during the crisis. Moreover, all ownership forms experience a productivity decline one year immediately after the crisis, although the magnitude of productivity losses differs considerably across ownership types. While shareholding ownerships are severely affected, productivity growth of cooperatives and NGOs deteriorates moderately. Because of policy distortions can be correlated with the productivity growth pattern (Ranasinghe, 2014), the poor performance of both shareholding ownerships during the crisis may reflects the vulnerability of existed regulatory framework during the crisis period. Although banks, cooperatives and NGOs show signs of recovery after two years of the crisis, NBFIs' poor performance remains stagnant. Taken together, I find that the pattern of productivity growth of all ownership types three years after the eruption of the crisis is remarkably similar to their productivity growth patterns in the very early phase of the pre-crisis period. Overall, the findings of this study are consistent with the view that microfinance ownerships focus more on profits, particularly those which are highly integrated into the local and foreign financial markets and those types largely expose to 'toxic assets' grow more in the market during a credit boom but suffer more when their funding sources are severely hit by the crisis and if there is a sudden withdrawal of deposits by clients. The empirical results under normal economic conditions (i.e., 2005/2006 and 2010/2011) are also consistent with the findings of Servin et al. (2012).

This study sheds light on which ownership forms are more robust to the crisis and which are more affected, and then provides explanations for the variations of their productivity growth. However, more empirical work needs to be done to understand why performance of shareholding ownerships have been more affected and why non-shareholding ownerships have been less affected by the global financial crisis, though they are more likely to have poorer governance mechanisms compared to their shareholding competitors. 


\section{References}

Ahlin, C., Lin, J., Maio, M., 2011. Where does microfinance flourish? Microfinance institution performance in macroeconomic context. Journal of Development Economics. 95, 105-120.

Armendáriz, B., Morduch, J., 2005. The Economics of Microfinance. Cambridge: The MIT Press.

Beltratti, A., Stulz, R. M., 2012. The credit crisis around the globe: Why did some banks perform better?. Journal of Financial Economics, 105(1), 1-17.

Benston, G.R., 1965. Branch banking and economies of scale. Journal of Finance, 20, 312-331.

Casu, B., Girardone, C., Molyneux, P., 2004. Productivity change in European banking: A comparison of parametric and non-parametric approaches. Journal of Banking and Finance, 28, 2521-2540.

Casu, B., Ferrari, A., Zhao, T., 2013. Regulatory reform and productivity change in Indian banking. Review of Economics and Statistics, 95(3), 1066-1077.

Chen, K. H., 2012. Incorporating risk input into the analysis of bank productivity: Application to the Taiwanese banking industry. Journal of Banking \& Finance, 36(7), 1911-1927.

Chen, K, H., Yang, H, Y., 2011. A cross-country comparison of productivity growth using the generalised metafrontier Malmquist productivity index: with application to banking industries in Taiwan and China. Journal of Productivity Analysis, 35, 197-212.

Chung, Y,H., Färe, R., Grosskopf, S., 1997. Productivity and undesirable outputs: a directional distance function approach. Journal of Environmental Management, 51:229-240.

Constantinou, D., Astha, A., 2011. Financial crisis: lessons from microfinance. Strategic Change, 20(5-6), 187-203.

Cull, R., Demirgu-Kunt, A., Morduch, J., 2007. Financial performance and outreach: a global analysis of lending microbanks. The Economic Journal. 117, 107-133.

Deutsche Bank Research, 2007. Microfinance: an emerging investment opportunity. Deutsche Bank, Frankfurt am Main, Germany.

Di Bella, C. G., 2011. The impact of the global financial crisis on microfinance and policy implications. IMF Working Papers, 1-40. 
Fahlenbrach, R., Prilmeier, R., Stulz, R. M., 2012. This time is the same: Using bank performance in 1998 to explain bank performance during the recent financial crisis. The Journal of Finance, 67(6), 2139-2185.

Färe, R., Grosskopf, S., Norris, M., Zhang, Z., 1994. Productivity growth, technical progress, and efficiency change in industrialized countries. The American economic review, 84(1), 66-83.

Färe, R., Grosskopf, S., Pasurka, C. A., 2007. Environmental production functions and environmental directional distance functions. Energy, 32, 1055-1066.

Fugii, H., Managi, S., Matousek, R., 2014. Indian bank efficiency and productivity changes with undesirable outputs: A disaggregated approach. Journal of Banking \& Finance, 38, 41-50.

Galema, R., Lensink, R., Spierdijk, L., 2011. International diversification and Microfinance. Journal of International Money and Finance, 30, 507-515.

Gutierrez-Niéto, B., Serrano-Cinca, C., \& Molinero, C.M., 2007. Microfinance institutions and efficiency. The International Journal of Management Science, 35, 131-142.

Gutierrez-Niéto, B., Serrano-Cinca, C., Molinero, C.M., 2009. Social efficiency in microfinance institutions. Journal of Operational Research Society, 60,104-119.

Hamed, Y., 2007. Efficiency drivers and constraints: Empirical findings. In Balkenhol, B. eds. Microfinace and Public Policy. Outreach, performance and efficiency. PALGRAVE MACMILLAN, New York, N.Y., \& International Labor Office, Geneva, Switzerland, pp. 126152.

Hartarska, V., Mersland, R., 2012. Which Governance Mechanisms Promote Efficiency in Reaching Poor Clients? Evidence from Rated Microfinance Institutions. European Financial Management, 18(2), 218-239.

Hermes, N., Lensink, R., Meesters, A., 2011. Outreach and efficiency of microfinance institutions. World Development. 39(6), 938-948.

Isik, I, Hassan, K., 2002. Technical Scale and Allocative Efficiencies of Turkish Banking Industry. Journal of Banking and Finance, 26 (2002), 719-766.

Ivashina, V., Scharfstein, D., 2010. Bank lending during the financial crisis of 2008. Journal of Financial economics, 97(3), 319-338.

Juo, J. C., Lin, Y. H., Chen, T. C., 2015. Productivity change of Taiwanese farmers' credit unions: a nonparametric metafrontier Malmquist-Luenberger productivity indicator. Central European Journal of Operations Research. 23(1), 125-147. 
Kevane, M., Wydick, B., 2001. Microenterprise lending to female entrepreneurs: Sacrificing economic growth for poverty alleviation?. World development, 29(7), 1225-1236.

Kollmann, R., Ratto, M., Roeger, W., 2013. Fiscal Policy, Banks and the Financial Crisis. Journal of Economic Dynamics \& Control, 37, 387-403.

Leightner, J.E., Lovell, C.A.K., 1998. The Impact of Financial Liberalization on the Performance of Thai Banks. Journal of Economics and Business, 50, 115-131.

Li, K., Lin, B., 2015. Metafroniter energy efficiency with CO2 emissions and its convergence analysis for China. Energy Economics, 48, 230-241.

Littlefield, E., Kneiding, C., 2009. The global financial crisis and its impact on microfinance. CGAP Focus Note 52. Washington DC.

Louis, P., Seret, A., Baesens, B., 2013. Financial efficiency and social impact of microfinance institutions using self-organizing maps. World Development, 46, 197-210.

Mersland, R., Strøm, R. Ø., 2008. Performance and trade-offs in microfinance organizationsdoes ownership matter?. Journal of International Development, 20, 598-612.

Mersland, R., Strøm, R., 2009. Performance and governance in microfinance institutions. Journal of Banking \& Finance, 33, 662-669.

Mester, L.J., 1996. A study of bank efficiency taking into account risk-preferences. Journal of Banking and Finance, 20, 1025-1045.

Nghiem, H.S., Coelli, T.J., \& Rao, D. S.P., 2006. The Efficiency of Microfinance in Vietnam: Evidence from NGO Schemes in the North and the Central Regions. International Journal of Environmental, Cultural, Economic and Social Sustainability, 2(5), 71-78.

O’Donnell, C.J., Prasada Rao, D.S., Battese, G.E., 2008. Metafrontier Frameworks for the Study of Firm-level Efficiencies and Technology Ratios. Empirical Economics, 34, 231-255.

Oh, D. H., Lee, J. D., 2010. A metafrontier approach for measuring Malmquist productivity index. Empirical Economics, 38(1), 47-64.

Park, K.H., Weber, W.L., 2006. A note on efficiency and productivity growth in the Korean Banking industry, 1992-2002. Journal of Banking and Finance, 30, 2371-2386.

Patten, R. H., Johnston, D. E., 2001. Microfinance success amidst macroeconomic failure: The experience of Bank Rakyat Indonesia during the East Asian crisis. World Development, 29(6), 1057-1069. 
Paxton, J., 2007. Technical Efficiency in a semi-formal financial sector: The case of Mexico. Oxford Bulletin of economics and Statistics, 69(1), 57-74.

Piot-Lepetit, I., Nzongang, J., 2014. Financial sustainability and poverty outreach within a network of village banks in Cameroon: A multi-DEA approach. European Journal of Operational Research, 234(1), 319-330.

Pitt, M. M., Khandker, S.R., 1998. The Impact of Group Based Credit Programs on Poor Households in Bangladesh: Does the Gender of Participants Matter? Journal of Political Economy. 106(5), 958-996.

Ranasinghe, A., 2014. Impact of policy distortions on firm-level innovation, productivity dynamics and TFP. Journal of Economic Dynamics \& Contro, 146, 114-129.

Robinson, M., 2001. The microfinance revolution: Sustainable finance for the poor. The World Bank, Washington, DC.

Schubert, S.F., 2011. The effects of total factor productivity and export shocks on a small open economy with unemployment. Journal of Economic Dynamics \& Control, 35, 1514-1530.

Sealey, C. W., Lindley, J. T., 1977. Inputs, outputs, and a theory of production and cost at depository financial institutions. The Journal of Finance,32(4), 1251-1266.

Servin, R., Lensink, R., van den Berg, M., 2012. Ownership and technical efficiency of microfinance institutions: Empirical evidence from Latin America. Journal of Banking \& Finance, 36, 2136-2144.

Shephard, R., W., 1970. Theory of Cost and Production Functions, Princeton: Princeton University Press.

Tchuigoua, H. T. (2014). Institutional framework and capital structure of microfinance institutions. Journal of Business Research, 67(10), 2185-2197.

Tchakoute-Tchuigoua, H., 2010. Is there a difference in performance by the legal status of microfinance institutions?. The quarterly review of economics and finance, 50(4), 436-442.

Wanger, C., 2012. From Boom to Bust: How Different Has Microfinance Been from Traditional Banking? Development Policy Review, 30 (2), 187-210.

Wagner, C., Winkler, A., 2013. The Vulnerability of Microfinance to Financial Turmoil Evidence from the Global Financial Crisis. World Development, 51, 71-90. 
Wijesiri, M, Meoli, M., 2015. Productivity change of microfinance institutions in Kenya: A bootstrap Malmquist approach. Journal of Retailing and Consumer Services, 25,115-121.

Wijesiri, M., Viganò, L., Meoli, M., 2015.Efficiency of microfinance institutions in Sri Lanka: a two-stage double bootstrap DEA approach. Economic Modelling, 47,74-83.

Zha, Y., Liang, N., Wu, M., Bian, Y., 2015. Efficiency evaluation of Banks in China: A dynamic two-stage slacks-based measure approach. Omega. 